\title{
補聴器の明瞭度とうるささ
}

\author{
涌井 慎哉・久保 富隆* ·斎藤 等*
}

\section{The Clarity and Noisiness of Sound with a Hearing Aid}

\author{
Shinya Wakui \\ (Wakui ENT Clinic)
}

Tomitaka Kubo and Hitoshi Saito

(Fukui Medical School)

\begin{abstract}
It is often said that with a hearing aid, sound is noisy and unclear but the cause of this is uncertain. Examinations of hearing aids are performed using continuous sine wave, i.e. pure tone. Daily sounds are, however, full of transient changes and quite different from pure tone. In this study, we used some special signals such as impulse, square wave, and single sine wave to examine hearing aids and found that the resonance of the receiver is the main cause of noisiness and lack of clarity. We also found that the higher the resonant frequency, the clearer and less noisy the sound of the hearing aid becomes. The fact that a high-difinition hearing aid, which has a receiver with a resonant frequency above the audible range, makes it possible to obtain both clarity and lack of noisiness at high levels suggests that improvement of the receiver is most important in the development and study of hearing aids.
\end{abstract}

Key words: hearing aid, clarity, noisiness, resonance, high-definition hearing aid

はじめに

補聴器のフィッティングの基本は, 補聴器装 用により言葉が明瞭に聴き取れるように充分な 利得を各周波数に対して持たせることである。 しかしながら難聴者ではリクルートメント現象 に見られるよらに聴覚のダイナミックレンジが 狭くなっていることが多いため，先汪どの方針 に従って利得を充分大きくするとレベルの高い 雑音などが狭くなったダイナミックレンジの上 限（不快閾值）を越えてやかましくなってしま ら。そこで明瞭度とやかましさを両立させるた
めに種々の対策が講じられてきた。これらの対 策の基本的な考方方は難聴者の狭くなったダイ ナミックレンジを越えるような大きな出力を補 聴器から出さないようにするというものである. そしてそのようなことを可能にすべくさまざま な信号処理の試みがなされてきた。それらの動 作の理論からは確かに注とんどの音が難聴者の ダイナミックレンジ内に収まるはずであるよう に思える。しかしながら現実には思ったほどの 効果は得られていない。これは補聴器の現実の 動作が期待されたようにはなっていないためで

わくい耳鼻科（箕面市）

* 福井医科大学耳鼻咽喉科学教室 
はないかと考えられる. 従来, 補聴器の出力の 波形については入力と相似となっているはずで あるといら楽観的な前提があり，この前提をも とに多くの研究, 開発が進められてきた. 今回 この前提が妥当なものであるかどらかを検討し， 補聴器の不明瞭さやうるささの原因について考 察を加えた。

\section{実験 1 : 補聴器の応答波形}

補聴器に入力した信号の波形がイヤホンから 出力されるときに，どのよらな波形になってい るかを調べるために以下の実験を行った.

〈方 法〉

1. 入力信号として, $400 \mathrm{~Hz}$ 方波形, $5000 \mathrm{~Hz}$ 半波 (極性交互, $1 \mathrm{msec}$ 毎), $1 \mathrm{kHz}$ 単発サイ ン波12)を用いた。

2.上記の信号をオシレータから発生させ, 増幅器を通して全帯域静電型スピーカーから出 力させた.

3. 実験に用いた補聴器は, 通常補聴器とし て RION の HA-33（イヤホンはRK-63B）およ び静電型イヤホンを使用してわれわれが試作し た, 高品位補聴器3) 6) と名付けたものを使用し た。
4. それぞれの補聴器はそのマイクロホンが スピーカー正面軸上 $10 \mathrm{~cm}$ に位置するように した。その位置に打けるスピーカーからの音圧 の較正は各信号の波形のピーク值が $70 \mathrm{~dB}$ 純音 のピーク值と等しくなるようにした。較正を ピーク值で行った理由は, 通常の実効レベルで 較正を行らと信号によってはピーク值が大きく なりすぎて実験に用いた静電型スピーカーを破 損させるためである.

5.カプラーの波形に対する影響を除外する ため, 補聴器の出力はカプラーなしで測定用マ イクロホンに入力した.

〈結 果〉（図 1)

出力波形の図に括ける横軸（時間軸）は波形 観察がしやすいように信号の種類ごとに変えて ある. 通常補聴器の場合, 一見して入力に対す る出力の波形は大きく崩れて元の波形とは決し て同じょうな形にはなっていないことがわかる。 このことから先ほどの前提, すなわち「補聴器 から出力される信号は入力された信号と波形的 に同等のものであろう」といら考皇は決して正 しいものではなく, 補聴器の入出力の波形が実 は相似になっていないことが明らかになった。
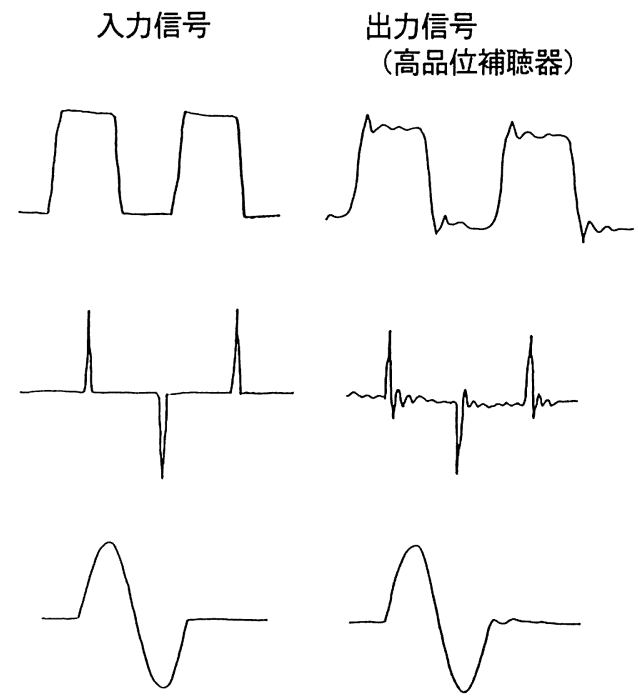

出力信号

(高品位補聴器)

\section{出力信号}

(通常補聴器)
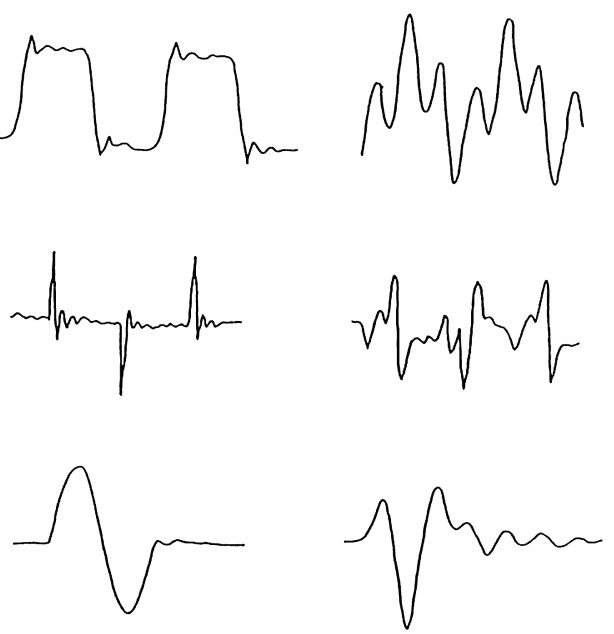

図 1 入力信号と出力信号の比較 
一方, 高品位補聴器では若干の波形の乱れはあ るものの入力された波形とほぼ相似形の出力波 形となって打り, 通常の補聴器と忠実度に扮い て大きな差異があることがわかった。

\section{実験 2 : 共振現象}

実験 1 と打ける補聴器の応答波形の乱れの原
因を、より詳細浪べるために次の実験を行っ た。

\section{〈方 法〉}

1. $1 \mathrm{kHz}$ から $20 \mathrm{kHz}$ までの各周波数の連 続サイン波(純音)抢よび単発サイン波をスピー カーから出力させた（原波形）。連続サイン波
連続サイン波
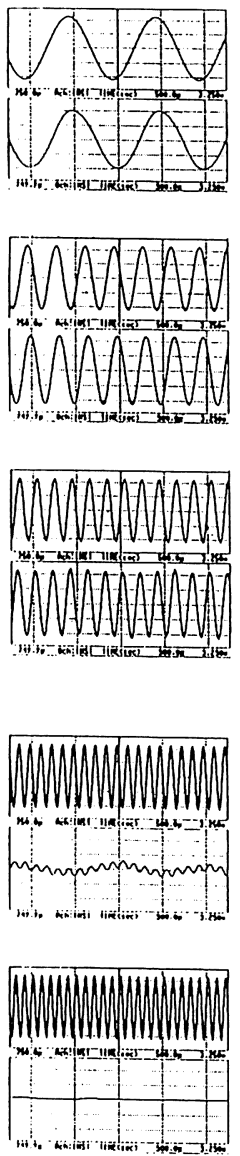

(上段：原波形 ）

(下段 : 応答波形)

単発サイン波

$1 \mathrm{kHz}$

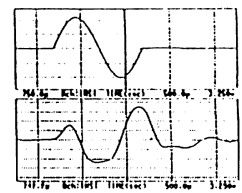

$3 \mathrm{kHz}$

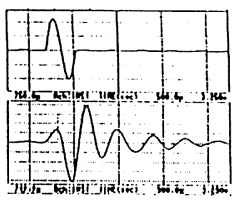

$5 \mathrm{kHz}$

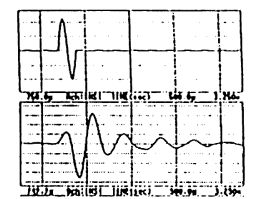

応答の周波数が入カと

異なっている

$8 \mathrm{kHz}$

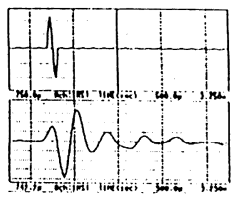

$10 \mathrm{kHz}$

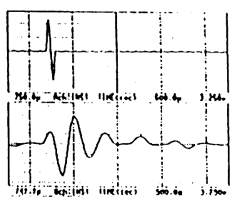

$20 \mathrm{kHz}$

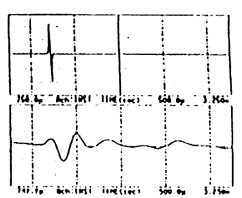

図 2 連続サイン波と単発サイン波とに対する応答 
の出カレベルは正面軸上 $10 \mathrm{~cm}$ の位置で 70 dBSPL になるようにし, 単発サイン波のレベ ルはそのピーク值が連続サイン波のものと同じ になるようにした。

2. 補聴器 (RION HB-90AO) のマイクロホ ンをスピーカー正面軸上 $10 \mathrm{~cm}$ に置いた. 補 聴器の出力は $2 \mathrm{cc}$ カプラーを介して測定用マ イクロホンに入力し (応答波形), 利得調整器 の位置については $1 \mathrm{kHz}$ に拈いて $20 \mathrm{~dB}$ の利 得となる位置に固定した。

〈結果および考察〉(図 2 )

定常的な波形である連続サイン波に対しては 波形の乱れはほとんどない。このような測定結 果をみて補聴器の入力に対する反応は何ら問題 がないとメーカーも研究者も考学ていたのであ る。しかしながら単発サイン波のような過渡的 変化を持つ波形に対しては，実験 1 の結果と同 様に，応答波形が乱れていることがわかった。 ここで単発サイン波に対する応答を検討すると， 次のような問題点が明らかになった。すなわち 入力がなくなった後も出力が尾を引いて長く残 るといら点, ある周波数（この例では $3 \mathrm{kHz}$ ) 以上の入力に対しては出力の周波数は変化せず 一定の周波数となる点, 連続サイン波では応答 のないよらな高い周波数の単発サイン波の入力 に対して大きな出力がみられる点などであった． これらの現象から補聴器にとって単発サイン波 はインパルス様信号として作用していると推測 され, これらの応答は音響的な自由振動 (共振) を起こした結果であると考えられた。

一般的に共振があると次のような現象を生ず る。

1 ) 出力には共振周波数以上の周波数の成分 が注とんど生じないため共振周波数以上 の成分を多く持つような複雑な入力信号 には正確に応答できない。

2) インパルス的な入力信号は共振周波数の 強い出力を引き起こすことにより入力信 号の周波数スペクトルを共振周波数に鋭 い山を持つ形に変化させる.
1）から補聴器が正確に応答できる(有用な) 周波数範囲は，たかだかその共振周波数までで あることが推測される. 補聴器の明瞭度を向上 させるためには複雑な信号に対する応答の正確 さが重要であるので, より良い明瞭度を得るた めには有用な周波数範囲を広げることすなわち 共振周波数を高くする必要があると考兄られる.

2）からはさまざまな音が補聴器を通すこと によりその音の周波数スペクトルが変化して補 聴器独特の音色となることがわかる. そして周 波数スペクトル上の鋭い山を生ずることは，そ れが可聴帯域にある場合その周波数のエネル ギーが強くなるため, 補聴器の音のやかましさ を生ずる原因の一つになり得ると考えられる. この山の位置は共振周波数によって変化するの で, 共振周波数の違いによって補聴器の音のや かましさも変わってくると考えられる.

\section{実験 $3:$ 聴感との相関}

ここで実際に，イヤホンの共振周波数の違い が明瞭度ややかましさにどのように影響してい るかを調べてみた。

〈方 法〉

1. 被験者は正常聴力者10名, 感音難聴者 14 名 (老人性, 高音漸傾型, 平均聴力レベルが 4 分法で $55.1 \mathrm{dBHL)}$ である.

2 . 検査音として, 語音 (67式語音テープ) 怙よび DAT に自己録音した現実音（紙を丸め る音など）を使用した。

3. 実験に用いた補聴器は(1)RION HA-33 (RK-6 1B), (2)RION HA-3 3 (RK-63B), (3)SONY TE-ST7, (4)高品位補聴器3) 6) である.

4. それぞれの補聴器の共振周波数は単発サ イン波応答12) の波形分析扣よびインパルス応 答の周波数分析により測定した. 周波数分析に は高速フーリエ変換 (FFT : fast fourier transform)を用いた。

5. 防音室内で検査音をスピーカー (STAX ELS-83X limited) より出し, スピーカー正面軸 上 $10 \mathrm{~cm}$ の位置に補聴器のマイクロホンを設 置して防音室外の被験者に聴取させた. 
6. 検査音は増幅器と抵抗組み合わせ型パッ シブアッテネータを組み合わせてレベルを細か く調整できるよらにし，現実音についてはその 平均のレベルが語音テープの $0 \mathrm{~dB}$ 基準レベル 信号のレベルと揃えるように調整した.

7 . 補聴器の利得調整器は $1 \mathrm{kHz}$ に扮いて 20 $\mathrm{dB}$ の利得となるように固定し, スピーカーか らの出力レベルを変化させることにより被験者 の聴取レベルを調整した.

8. スピーカーの入出力特性については正面 軸上 $10 \mathrm{~cm}$ に扔いて $0 \mathrm{dBSPL}$ から $110 \mathrm{dBSPL}$ の出力まで直線性が保たれていることを確認し た。

9. 補聴器の入出力特性についても入力が 0 dBSPL から $110 \mathrm{dBSPL}$ まで出力の直線性が保 たれていることを確認した。

10. 語音明瞭度試験に準じて語音明瞭度曲線 を得た。そしてその明瞭度曲線において最大語 音明瞭度にいたるスピーカー出力の最低レベル を Lmin とした。このレベルは語音についてほ ぼ満足できる明瞭度を得られる最小入力レベル であるので，実用最小入力レベルと考えられる．

11. 現実音についても同様にレベルを变化(上 昇法）させ，やかましくて我慢できなくなるス ピーカーからの出カレベル（L) を求めた． L 以上のレベルの入力に対する出力の音はやかま しくて聴いていられないので，Lは実用最大入 カレベルと考えられる.

12. 補聴器を使用した場合, 入力が Lmin 以 下のレベルでは明瞭度が不足し, L 以上のレベ ルではやかましくて聴いていられない。したが って，実用となる入力の音圧レベルの範囲は実 用最小レベルから実用最大レベルまで，すなわ ち Lmin からLまでとなる。ここで (L-Lmin) の值を実用ダイナミックレンジと呼ぶことにす る.この值はその補聴器を使用して会話音を満 足な明瞭度で聴取できる利得にしたときに，ど のくらい大きな入力レベルの雑音まで我慢でき るかを示している.すなおちその補聴器の実使 用時に怙けるやかましさの指標となり得ると考
えられる。

13. 補聴器による明瞭度の比較の指標として, それぞれの補聴器で得られた最大語音明瞭度 （\%）を使用した。これはその補聴器がもたら し得る最大の語音明瞭度と考兄られる。

14. 補聴器によるやかましさの比較の指標と して, それぞれの補聴器で求められた実用ダイ ナミックレンジを使用した。

〈結 果〉(図 3 )

明膫度についてみると，予想したように共振 周波数の高いものの方が明瞭度が上がる傾向が あることが示された。それぞれの補聴器で最大 語音明瞭度を得た出力音圧については, 補聴器 の周波数特性がそれぞれ異なるため正確に比較 することはできないが, $1 \mathrm{kHz}$ の利得でみる限 り補聴器によってほとんど差は認められなかっ た.

次に実用ダイナミックレンジについてみてみ ると, 明らかに共振周波数が高いものの方が良 好な結果を示した。 中でも共振周波数が 3.8 $\mathrm{kHz}$ と $8 \mathrm{kHz}$ との間には有意な差がみられた。 これは難聴者群では高音漸減型のため, 3.8 $\mathrm{kHz}$ と $8 \mathrm{kHz}$ の間で閾值差が大きく, $8 \mathrm{kHz}$ の 聴力が汪とんどないような被験者では, (3)や(4) の補聴器において, やかましくて我慢できない レベル（L）が非常に高くなったことによると

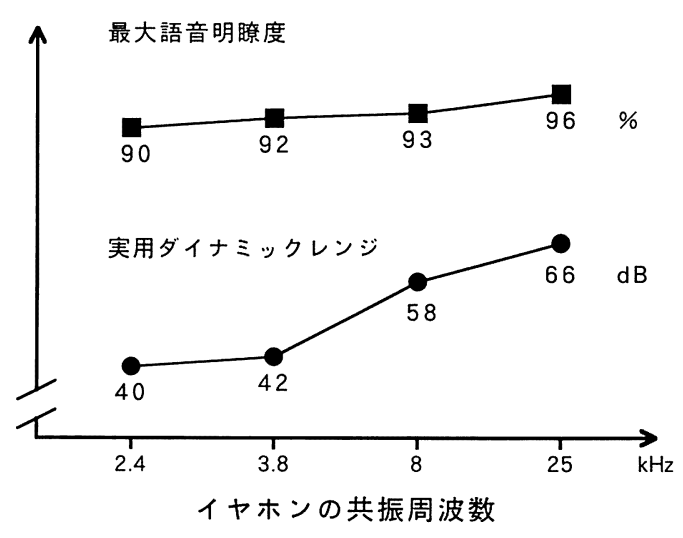

図 3 共振周波数の違いによる明瞭度と やかましさの違い 
考えられる. 補聴器の出力のスペクトルが共振 周波数の山を持つことから，共振周波数がその 人の可聴帯域外にあればやかましさをほとんど 感じないのではないかと予想されたが，今回の 実験の結果はそのことの一つの実証となったと いえる.

補聴器の明瞭度とやかましさのないこととの 両立の程度を示す指標は種々のものが考兄られ る. 補聴器の実使用時のことを考学ると, 補聴 器を使用できる最大レベルである L（我慢の限 界）と充分な語音明瞭度が得られる最低レベル Lmin との間がどれほどとれるかといらことが 重要である.これは今回使用した実用ダイナミ ックレンジそのものであり，この指標が明瞭度 とやかましくないこととの両立の程度を良く示 していると考觉られる。

\section{考按}

以前より補聴器の明瞭度改善, 万るささ軽減 をめざした種々の対策が考案されている，不明 瞭さに対しては信号処理による音圧的，時間的 コントラストの強調の試みがされているが充分 な効果はでていない．またやかましさについて は種々の出カコントロールの試みがされてい る477). これらの対策の基本的な考方方は難聴 者の狭くなったダイナミックレンジを越えるよ らな大きな出力を補聴器から出さないようにす るといらものである，そのほとんどは電気的な 信号処理を主体にしたものであって，なかには ディジタル技術を駆使して非常に細かく周波数 帯域を分割してそれぞれのダイナミックレンジ を難聴者のダイナミックレンジに合わせてコン トロールするといったものまで現れてい

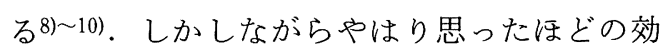
果は得られていないのが現状である.このよう に従来の音質対策がうまくいっていない原因の 一つは，このねらいを実現させるための手段が 信号処理でしかなかったということであろう. 機械的な問題点を解決しないままいくら信号処 理に力を注いでも，作り出された信号自体が実 際に出力されるときには波形的にも周波数スペ
クトル的にも期待された信号とは全く異なった ものとなっていたのである.これでは何のため に帯域毎のきめ細かなコントロールをしたのか わからない。

このような現象を起こす大きな原因の一つに 機械的共振があげられる。これを解決すること が重要な課題である.この機械的な共振を電気 的に補正することは可能であろらか. 結論的に は現実的には非常に困難であると言わざるを得 ない.まずインパルスに対して共振周波数以上 の出力スペクトルを持たせることは物理的に不 可能である．また共振の鋭さをコントロールす ることも困難である. 本格的に対策を行うとす ると, イヤホンの振動板に対する駆動能力を上 げて共振を抑兄込むことになるらが，方法とし てはアンプの電源インピーダンスを低くし, 位 相特性を優秀なものにし11), 内部抵抗を低くし (あるいは負性インピーダンス駆動), あるいは 振動板をフィードバック回路に取り入れるなど コストのかかる大がかりなものになってしまう． しかもそれが成功するかどらかは保証されてい ない，一方簡単な電気的処理で共振のうるささ を抑えようとするとイヤホンの共振周波数付近 から上の帯域を鋭くカットする必要がある. 例 えば共振周波数が $2.5 \mathrm{kHz}$ の場合では $2 \mathrm{kHz}$ あたりより上は出さないといらようなことにな る.このようにすれば共振周波数の出力は活と んど出てこなくなるのでうるささはかなり抑え られるであろら。しかしそのようなことをすれ ば明瞭度が悪くなってしまうのは明らかである。 補聴器の音のらるささを解決しょうとする場合, もし補聴器の共振周波数が低いままであると， たとえらるささは減少したとしても明瞭度との 両立は非常に困難であるといらことである。現 実問題としてこれらの問題を解決する道として は補聴器の共振周波数自体を上げるしかない. 実際, 共振周波数を上げた（可聴帯域外）イヤ ホン（静電型）を使用して試作された高品位補 聴器（図 2,3 ）では, 特殊な信号処理を全く していないにもかかわらず明瞭度とやかましさ 
のないこととの両立がかなりのレベルで実現で きた3) 5).イヤホンの改良だけでそのよらな成 果をあげられることを考えると，複雑な信号処 理に頼る前にまだまだ基本的になすべきことが ありそらである。具体的に今後の補聴器の性能 向上を考えるとき, 確かにマイクロホン, アン プにも問題はある. しかしながら何にもまして イヤホンが最大の問題である.それはいまだに 前時代的なマグネチック型が主流であって，そ の性能的限界は非常に低い，これを何とかしな い限り今後のあらゆる研究開発の努力が砂上の 楼閣となる恐れがある. 今後の課題として, よ り正確な波形再現の可能な上質のイヤホンの開 発を期待するものである.

\section{まとめ}

1. 補聴器の入出力波形を検討し, 出力の波 形がイヤホンの周波数特性の問題により決して 入力と相似にはならないことを確認した.

2 . 単発サイン波による測定を行い従来の連 続サイン波による測定では明らかにすることの できなかった補聴器の共振の問題を指摘した.

3 . 補聴器の共振が補聴器の音の不明瞭さと やかましさの原因になっていると考光，その共 振の周波数が実際の音の不明瞭さとやかましさ にどのような関係を持っているかを検討した.

4. 明瞭度については共振周波数が高いもの 注ど明瞭度が改善される傾向を認めた。これは 補聴器の出力信号が入力の情報により正確にな るためであると考えられた。

5.やかましさについては共振周波数が高い ものほどやかましさが減少することが認められ た.これは補聴器の出力の周波数スペクトルが 共振周波数中心のピークを持つものになるため ピークの周波数が聴覚の感度の低い周波数に移 動するためであると考えられた。

6 . 機械的共振は電気処理によっては解決困 難であり, 補聴器の音質上の問題点を解決する 手段としては共振周波数を上げることが最も有 効であると思われた。

7. 共振を解決しないままではさまざまな信
号処理の研究が無意味なものになる危惧があり, 現在使用されているイヤホンの早急の改良が望 まれる。

なお，本論文の要旨は，第36回日本オージオロジー 学会, 第21回国際オージオロジー学会でロ演した.

\section{文献}

1) 久保富隆, 涌井慎哉, 斎藤 等: 補聴器の単発 サイン波応答 一補聴器の重大な問題点一. Audiology Japan 34 : 357 358, 1991.

2) 涌井慎哉, 久保富隆, 斎藤 等: 補聴器の単発 サイン波応答一聴感との相関一. Audiology Japan $34:$ 359 360, 1991.

3) 涌井慎哉, 斉藤武久, 斎藤 等 : 高品位補聴器 の臨床的有用性に関する検討. Audiology Japan 31 : 291 292, 1988.

4）涌井慎哉, 久保富隆, 鹿野佳子, 他 : 高品位補 聴器の臨床的有用性に関する検討（第 2 報） 一歪率の実測扣よび周波数特性の適合に関する 実験一. Audiology Japan 32 : 309 310, 1989.

5) 涌井慎哉, 久保富隆, 斎藤 等 : 低歪補聴器に よる快適な補聴効果. Otology Japan 1:173， 1991.

6) 涌井慎哉, 久保富隆, 斎藤 等: 高品位補聴器 の臨床的有用性に関する検討（第 3 報）一ダ イナミックレンジュンプレッションの効果につ いての検討一. Audiology Japan $33:$ 673〜 674, 1990.

7) 大和田健次郎 : エキスパンダ増幅補聴器の試作. Audiology Japan $34:$ 343 344, 1991.

8）浅野 太, 鈴木陽一, 曽根敏夫, 他：ラウドネ ス写像型ディジタル補聴器の試作（その1）.

Audiology Japan 33 : 164 165, 1990.

9）大山健二, 矢畑誠治, 佐竹充章, 他: ラウドネ ス写像型ディジタル補聴器の臨床応用（第一 報). Audiology Japan 33 : 166〜167, 1990.

10）矢畑誠治, 浅野 太, 大山健二, 他：ラウドネ ス写像型ディジタル補聴器の臨床応用（第二 報). Audiology Japan $34: 339 \sim 340,1991$.

11）小関芳宏: 補聴器の高品位化への試み. Audiology Japan 34 : 341 342, 1991.

$$
\left(\begin{array}{c}
\text { 別刷請求先 : 涌井慎哉 } \\
\overline{\mathbf{T}} 562 \text { 箕面市小野原東5-8-6 } \\
\text { 方ーキ-K } 1 \text { 階 } \\
\text { わくい耳鼻科 }
\end{array}\right)
$$

